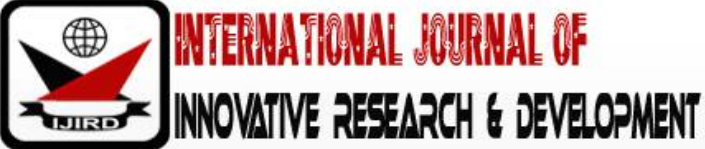

ISSN 2278 - 0211 (Online)

\section{Authentic Leadership and Organizational Trust in Improving Company Performance with Innovative Behavior as Intervening: Case Study of BCA KCU Yogyakarta, Indonesia}

\author{
\begin{tabular}{|c|}
\hline Rohman Ardhi \\
Student, Faculty of Economy, Universitas Islam Indonesia, Indonesia
\end{tabular}
}

\begin{abstract}
:
Development in a company requires major capital that is human resources. It has long been understood that human resources $(\mathrm{HR})$ is the first and foremost factor in advancing the welfare of a company. Human resources are one of the most important components that make up an organization, and their activities in the organization are the main driving force to facilitate change and improvement and to achieve organizational goals for sustainable development. Employees, the main human resources that make up an organization, contribute to the organization's development and success by fulfilling their duties and work. To achieve its job the company must have employees who believe in the organization and leadership in accordance with company goals. This research was conducted at BCA KCU Yogyakarta using a questionnaire to all employees and questionnaires obtained by 175 respondents. The questionnaire obtained in the analysis uses PLS to get the results of 7 hypotheses. The results of the study show that authentic leadership influences performance as well as innovative behavior and organizational trust influences innovative performance and behavior. The results of research can help companies or organizations to be able to improve performance by increasing employees' innovative behavior.
\end{abstract}

Keywords: Authentic leadership, organizational trust, innovative behavior and performance

\section{Introduction}

Development in a company requires major capital that is human resources. It has long been understood that human resources (HR) is the first and foremost factor in advancing the welfare of a company. Human resources are one of the most important components that make up an organization, and their activities in the organization are the main driving force to facilitate change and improvement and to achieve organizational goals for sustainable development. Employees, the main human resources that make up an organization, contribute to the organization's development and success by fulfilling their duties and work. To accomplish this task, employees continue to collaborate with other members of the organization such as coworkers and their leaders and participate in organizational activities. Through collaboration and communication with members of the organization, employees share organizational values, and develop and shape organizational attitudes that are directly or indirectly related to organizational performance.

The development of BCA has always increased from year to year. As a banking company that always offers breakthroughs or innovations in the financial world, it has even become a pioneer in various banking services such as $\mathrm{M}$ Banking, ATMs etc., BCA is required to have innovative and creative human resources. The development of banking in Indonesia is experiencing rapid progress at this time

There is no research that examines the relationship between authentic leadership, organizational trust and performance through innovative behavior, then this study discusses the influence of authentic leadership and organizational trust on company performance with innovative behavior as intervening at BCA KCU Yogyakarta.

\subsection{Problem Formulation}

Seeing the problems that exist in improving the performance of BCA KCU Yogyakarta and supported by the existence of a research gap in the research framework. then this research formulates the formulation of the problem in this study are:

- Is there an authentic leadership influence on innovative behavior?

- Bliss there an authentic leadership influence on performance?

- Is there an influence of organizational trust on innovative behavior?

- Is there any influence of organizational trust on performance?

- Is there an influence of innovative behavior on performance?

- Are there authentic leadership influences on performance through innovative behavior?

- Is there an influence of organizational trust on performance through innovative behavior? 


\subsection{Research Objectives}

The objectives of this research are:

- To find out the effect of authentic leadership on innovative behavior?

- To know authentic leadership on performance?

- To find out the organization's trust in innovative behavior?

- To find out the effect of organizational trust on innovative behavior?

- To find out the effect of innovative behavior on performance?

- To find out the effect of authentic leadership on performance through innovative behavior?

- To find out the effect of organizational trust on performance through innovative behavior?

\subsection{Research Benefits}

This research is expected to provide useful results both directly and indirectly for various parties, both for practitioners and academics, including:

- For BCA KCU Yogyakarta, it is hoped that the results of this study can be used as input on the role of authentic leadership and organizational confidence in improving the quality of performance to face competition and increase market share.

- For the government, it is expected that the results of this study can be taken into consideration in formulating policies related to the banking system.

- Give benefits as a reference for further research. This research can be developed by further research so that deeper results can be obtained and can be applied to real life.

\section{Literature Review}

The importance of authentic leadership in a company or organization is also supported by Kim's 2014 research, which states that authentic leadership can have a positive and significant effect on employee innovative behavior and company performance. This research uses several statistical techniques such as bootstrapping procedures and structural equation modeling (SEM). Around 2,500 Korean workers were selected as prospective survey participants, and of this number, 365 workers participated in the online survey.

Kim (2015) who said the same thing that organizational trust can improve innovative behavior and increase knowledge sharing so that employees are better at increasing creativity at work.

Dorner, (2012) Innovative Work Behavior: The Roles of Employee Expectations and Effects on Job Performance. This research was conducted in Germany and the results showed that innovative behavior as an intervention variable had a positive effect on performance.

\subsection{Theoretical Foundations}

\subsubsection{Authentic Leadership}

Leaders (leaders) and leadership (leadership) are two different concepts. Leaders are individuals who are able to influence group or organizational members in order to encourage the group or organization in achieving its goals. While leadership is the nature of the application of influence by a member of a group or organization against other members to encourage the group or organization in achieving its goals (Lussier, 2010).

\subsubsection{Organizational Trust}

Trust is the main key to creating a healthy or good relationship. Trust is considered an action, behavior or orientation, a relationship. Trust has been described as a cognitive action (for example a form of opinion or prediction that something will happen or people will behave in a certain way), affective (such as a matter of feeling) or conative (for example a matter of choice or desire). trust is a basic element for the creation of a good relationship. (Hanks. 2002)

\subsubsection{Innovative Behavior}

Innovative behavior according to Price (1997) basically is the ability of individuals to change the way work in the form of adopting new procedures, practices and work techniques in completing tasks and work. Gaynor (2002), defines innovative behavior as individual actions to create and adopt ideas / thoughts or new ways to be applied in the implementation and completion of work. According to De Jong and Kemp (2003) innovation can be interpreted as all individual actions directed at organizational interests in which introduction and application of new ideas are beneficial.

\subsubsection{Performance}

In general, performance is the result of quality and quantity of work that can be achieved by someone in carrying out their main tasks and functions in accordance with the responsibilities assigned or given to them. The term performance is a diversion from English, namely performance. Bernadin and Rusel (1993: 378) provide performance definitions as records of results obtained from certain job functions. Performance is the level of achievement of organizational goals. 


\subsection{Hypothesis}

- Authentic Leadership and Innovative Behavior

- Authentic Leadership and Performance

- Innovative organizational trust and behavior

- Organizational Trust and Performance

- Innovative Behavior Towards Performance

- Authentic Leadership on Performance through Innovative Behavior

- Organizational Trust in Performance through Innovative Behavior

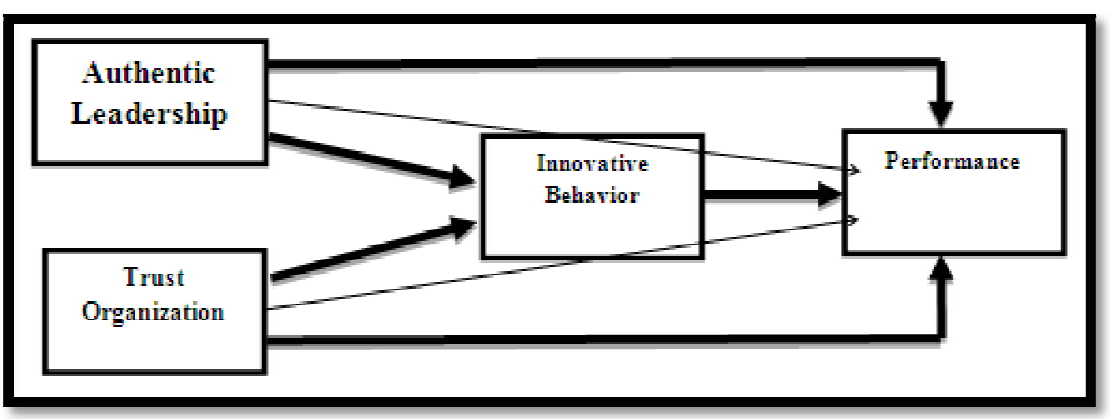

Figure 1

\section{Research Methods}

The population used in this study were 175 employees of BCA KCU Yogyakarta (one seventy-five employees). This study takes the entire population to be analyzed in terms of the influence of authentic leadership and organizational trust on company performance through innovative behavior. The population in this study meets the criteria for analysis using Partial Least Square (PLS). In a study, usually a researcher will experience conditions where the size the sample is quite large, but the researcher's theoretical foundation is still weak in terms of the relationship between the hypothesized variables.

\subsection{Sources and Data Collection Techniques}

The data sources that the compilers use in this study are primary data.

- Primary data is data obtained from the first source that is the researcher directly obtains data from the source (Gani \& Amalia, 2015, p. 2). The primary data that the compiler uses is taken from the questionnaire results given to respondents.

- The primary data used in this study was taken from the questionnaire results given to 190 BCA KCU Yogyakarta employees.

- Secondary data. Secondary data is data taken from the second source. The secondary data from this study are data from several literature studies.

\subsection{Definition of Variable Operations}

This study uses 2 independent variables namely authentic leadership and organizational trust. The dependent variable used in this study is company performance and the relationship between independent and dependent variables through innovative behavioral variables. The indicators and measurements of each variable are as follows:

\subsubsection{Authentic Leadership}

- Self-awareness (Self-awareness)

- Balanced-Processing Management

- Relationship transparency (Relational transparency)

- The moral internalized perspective (internalized-moral perspective)

\subsubsection{Organizational Trust}

- Trust in superiors

- Trust in coworkers

- Trust in the organization

\subsubsection{Innovative Behavior}

- Opportunity exploration

- Idea generation

- Championing

- Application 


\subsubsection{Performance}

- Productivity

- Quality of Service

- Responsiveness

- Responsibility

- Accountability

\subsection{Partial Least Square (PLS)}

In research, often a researcher will be faced with conditions where the sample size is quite large, but the theoretical basis is weak in terms of the relationship between the hypothesized variables. However, it is not uncommon to find very complex relationships between variables, but the sample size of the data is small. So, Partial Least Square (PLS) can be used to overcome these problems (Haryono, 2017).

Partial Least Square (PLS), using two evaluation model measurements in the analysis test, namely 1) Outer Model aims to test the validity and reliability; 2) Inner Model aims to test quality (testing hypotheses to test with predictive models).

\subsubsection{Evaluation of the Measurement Model (Outer Model)}

Outer models are often also called (outer relations or measurement models) which define how each block of items relates to their latent variables. The measurement model (outer model) is used to assess the validity and reliability of the model. Validity test is conducted to determine the ability of research instruments to measure what should be measured (Abdillah 2009). While the reliability test is used to measure the consistency of measuring instruments in measuring a concept or it can also be used to measure the consistency of respondents in answering statement items in a questionnaire or research instrument.

Further explanation of the measurement model (outer model) using the Convergent Validity, Discriminant Validity and Composite Reliability tests are as follows:

\subsubsection{Corvergent Validity}

Convergent validity measures the magnitude of the correlation between constructs and latent variables. Testing convergent validity can be seen from the loading factor for each construct indicator. The loading factor value $>0.7$ is an ideal value, meaning that the indicator is valid to measure the construct that was made. In empirical research, the loading factor value $>0.5$ is still accepted. In fact, some experts accept 0.4 . This value shows the percentage of constructs able to explain the variations that exist in the indicator (Haryono, 2017).

\subsubsection{Discriminant Validity}

Discriminant validity occurs when two different instruments that measure two constructs that are predicted to be uncorrelated produce scores that are not correlated (Hartono, 2008: 64 in Jogiyanto, 2011). Discriminant validity of the reflective model is evaluated through cross loading then comparing the AVE value with the square of the correlation value between constructs / comparing the square root of AVE with the correlation between constructs. The size of cross loading is to compare the correlation of indicators with other block constructs. If the correlation between indicators and constructs is higher than correlation with other blocks, this shows that the construct predicts the size of their blocks better than other blocks. Another measure of discriminant validity is that the root value of AVE must be higher than the correlation between constructs and other constructs or the value of AVE is higher than the square of correlation between constructs (Haryanto, 2017).

\subsubsection{Composite Reliability}

Measuring the reliability of a construct with reflexive items can be done in two ways, namely with Cronbach's Alpha and Composite Reliability. Composite Reliability (CR) is better in measuring internal consistency than Cronbach's Alpha because $\mathrm{Cr}$ does not assume the same boot of each indicator. Cronbach's Alpha tends to underestimate Composite Reliability. The interpretation of Composite Reliability is the same as Cronbach Alpha. A limit value of $\geq 0.7$ is acceptable and a value of $\geq 0.8$ is very satisfying. Another measure of convergent validity is the Average Variance Extracted (AVE) value. AVE values describe the magnitude of the variance or diversity of manifest variables that can be owned by latent constructs. Thus, the greater the variance or diversity of manifest variables that can be contained by latent constructs, the greater the representation of manifest variables to their latent constructs.

\subsection{Structural Model Evaluation (Inner Model)}

The specification of the relationship between latent variables (structural model) is what is called the Inner Model or also called the inner relation, describing the relationship between latent variables based on the substantive theory of research.

\subsubsection{R-Square (R2)}

To evaluate the structural model is to look at the significance of the relationship between variables. Changes in the value of R-squares (R2) can be used to explain the effect of certain independent latent variables on the dependent latent variable. The R2 criteria consist of three verifications, namely: $\mathrm{R} 2$ values $0.67,0.33$ and 0.19 as substantial, moderate and weak. 


\subsubsection{Hypothesis Testing (Bootstrapping)}

In assessing the significance of influence between variables, the bootstrapping procedure needs to be done. The bootstrap procedure uses all of the original 66 to do resampling again. Hair et al., 2001 in Ghazali and Latan (2015) suggest that the number of bootstrap samples is 5,000, provided that the number must be greater than the original sample. In bootstrap resampling, the significance value used (two-tailed) t-values was 1.65 (significance level $=10 \%$ ), 1.96 $($ significance level $=5 \%)$ and $2.58($ significance level $=1 \%)$.

\subsection{SEM Analysis with Mediation Effects}

Testing the effects of mediation in the analysis using PLSusing a procedure developed by Baron and Kenny (1986) with the following stages:

- The first model, examines the effect of independent variables on the dependent variable and must be significant at t-statistics greater than 1.96 .

- The second model examines the effect of independent variables on intervening variables and must be significant at t-statistics greater than 1.96 .

- The third model, simultaneously testing the effect of independent and intervening variables on the dependent variable.

\section{Data Analysis and Discussion}

4.1. Validity and Reliability

\begin{tabular}{|l|c|ll|}
\hline \multicolumn{1}{|c|}{ Variabel } & $\begin{array}{c}\text { Composite } \\
\text { Reliability }\end{array}$ & \multicolumn{1}{c|}{ AVE } \\
\hline Authentic leadership & 0.941 & 0.616 \\
\hline Organizational Trust & 0.971 & 0.606 & \\
\hline Innovative behavior & 0.969 & 0.608 & \\
\hline Performance & 0.967 & 0.676 & \\
\hline
\end{tabular}

Table 1

\subsubsection{First Stage}

Source: Primary data processed 2019

The first step in testing the effects of mediation is to examine the effect of exogenous variables on endogenous variables and must be significant at a t-statistic $>1.96$.

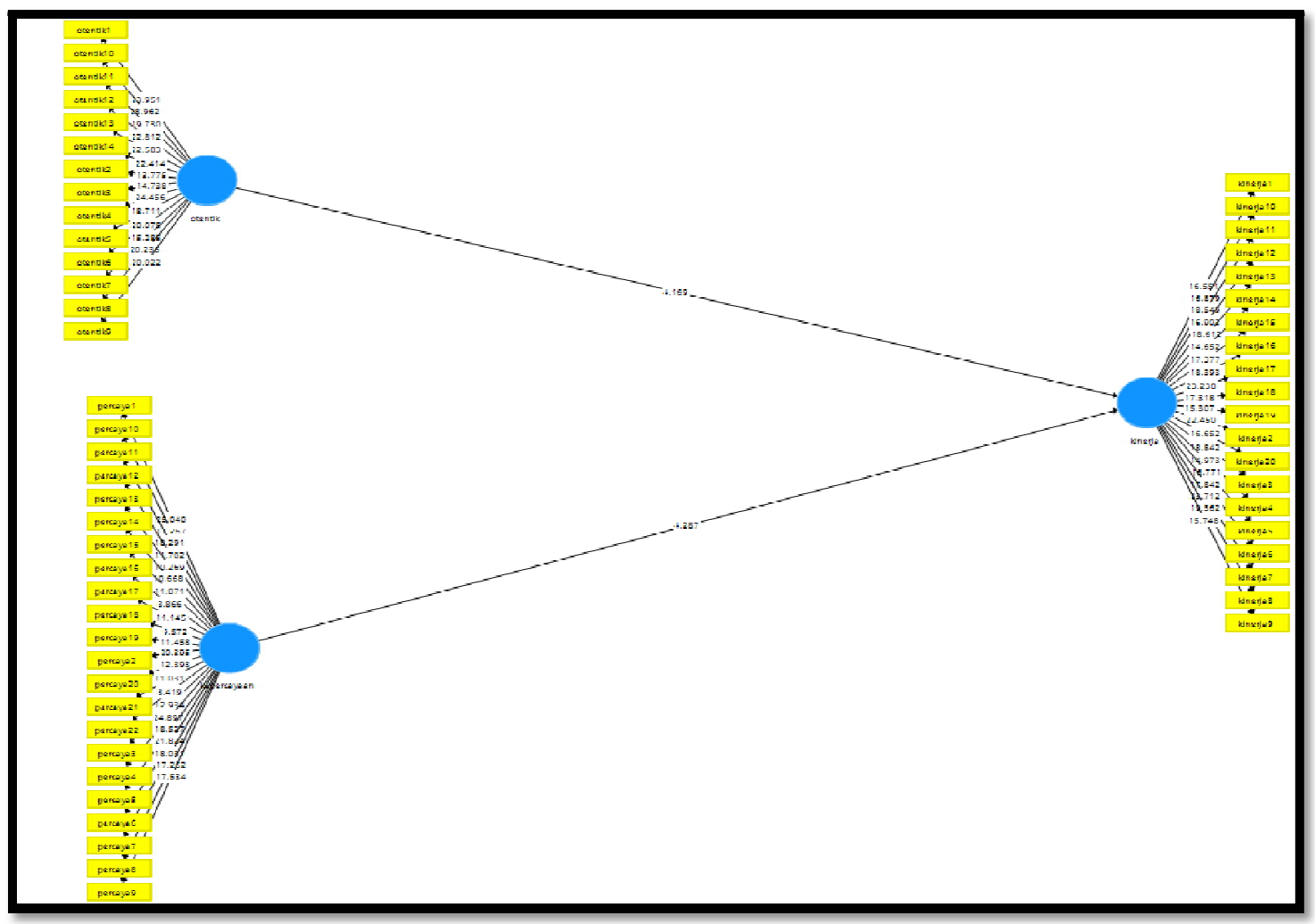

Figure 2

\subsubsection{Second Stage}

At this stage, a significance test is performed between exogenous variables and mediation variables and must be significant at the t-statistic value $>1.96$ 


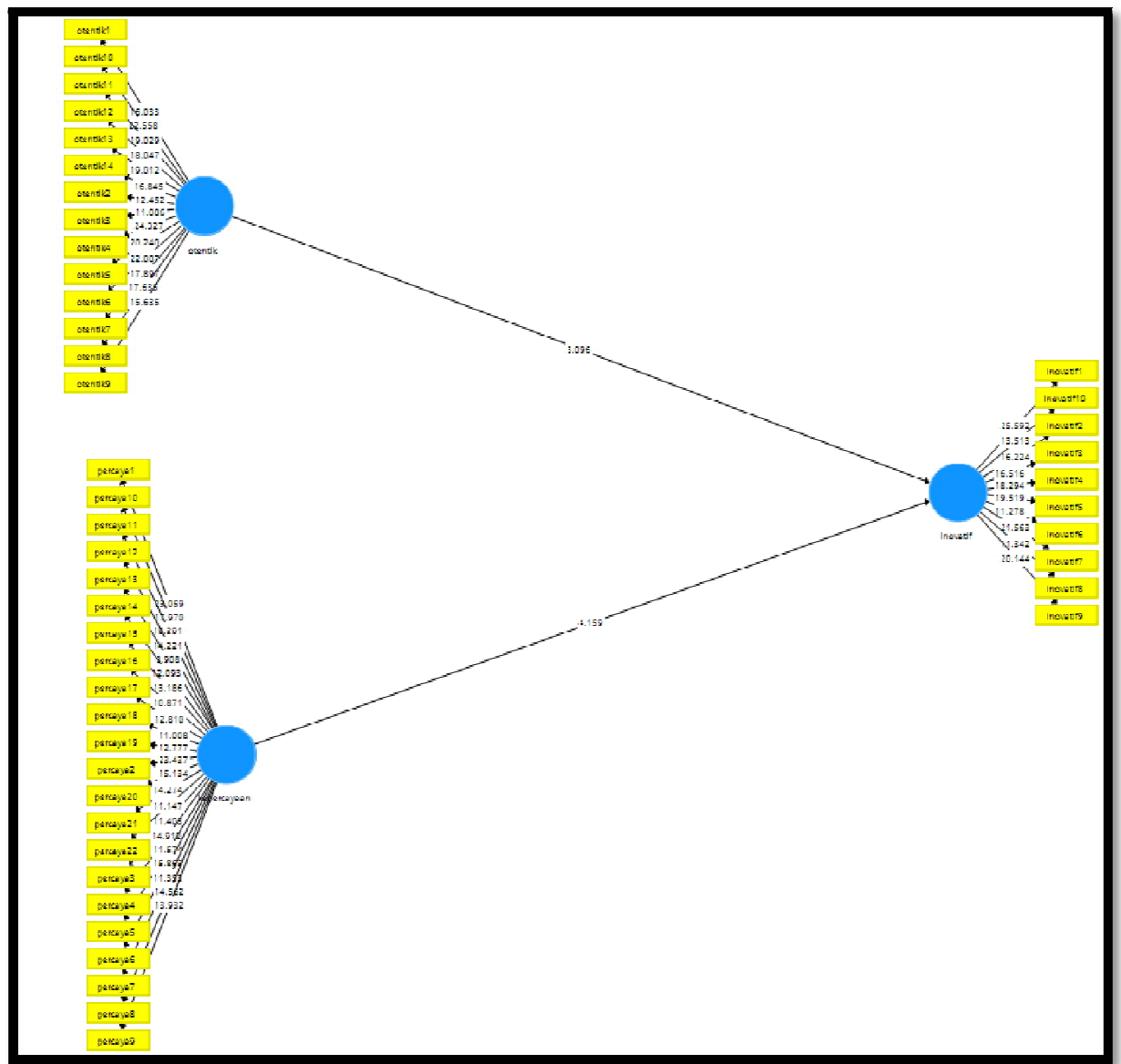

Figure 3

\subsubsection{Third Stage}

At this stage simultaneous testing of authentic leadership exogenous variables, organizational trust, and innovative behavioral mediating variables on endogenous performance variables.

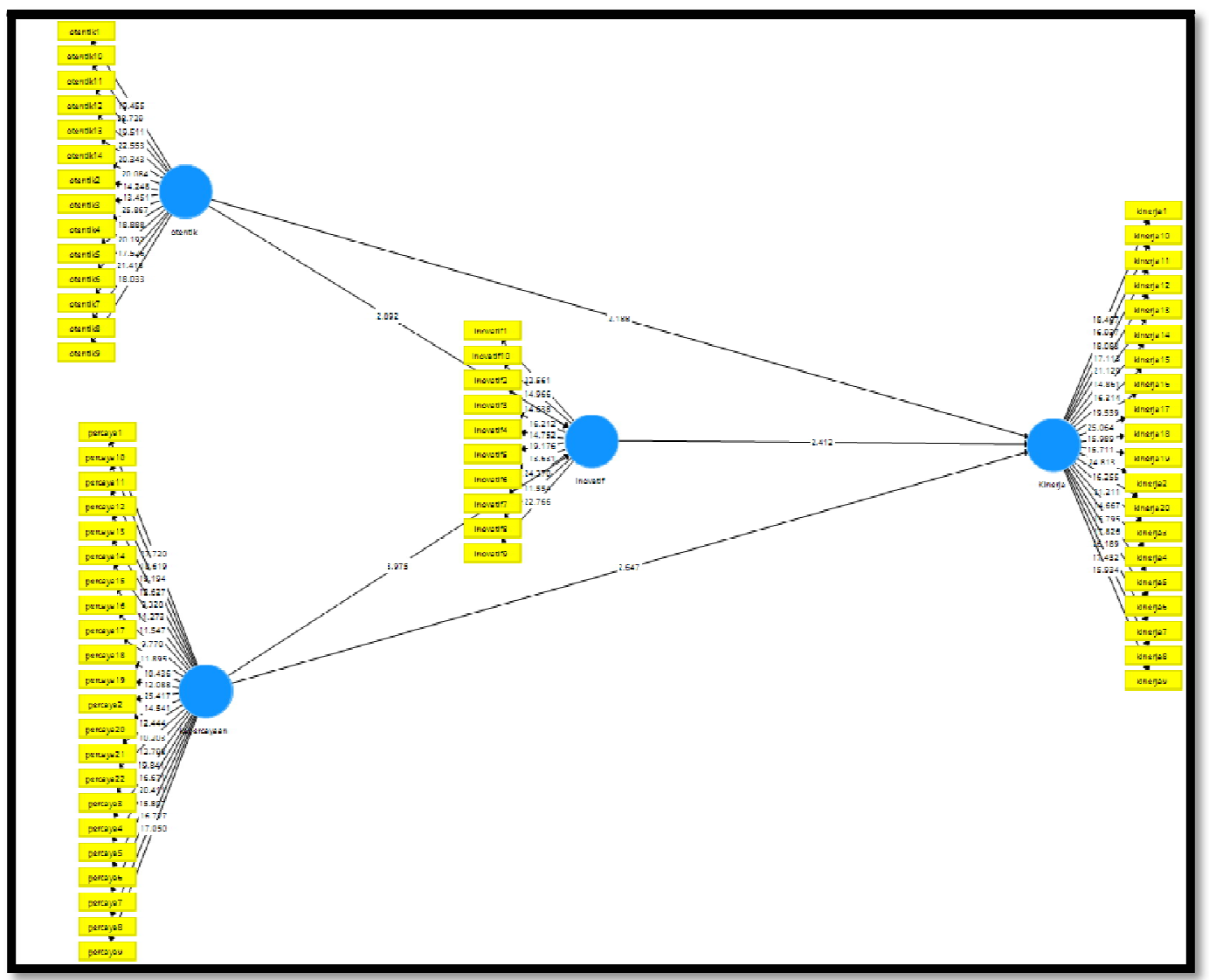

Figure 4 
That the value of all variables in reliability testing both uses Composite Reliability values $>0.70$, and validity testing using AVE (Average Variance Extracted) values $>0.50$. In authentic leadership variables $0.941>0.70$ and AVE value $0.616>0.50$ then authentic leadership variables are valid and reliable. On the reliability variable organizational reliability $0.971>0.70$ and AVE value $0.606>0.50$, the organizational trust variable is valid and reliable. On the innovative behavior variable reliability $0.969>0.70$ and AVE value $0.608>0.50$ then the innovative behavior variable is valid and reliable. And the reliability performance variable $0.967>0.70$ and AVE value $0.676>0.50$ then the performance variable is valid and reliable.

\begin{tabular}{|c|c|c|c|}
\hline No & Hipotesis & P Values & Kesimpulan \\
\hline 1 & $\begin{array}{c}\text { Authentic leadership has a positive } \\
\text { influence on innovative behavior }\end{array}$ & 0.001 & Proven \\
\hline 2 & $\begin{array}{c}\text { Organizational trust has a positive } \\
\text { influence on innovative behavior }\end{array}$ & 0.000 & Proven \\
\hline 3 & $\begin{array}{c}\text { Authentic leadership has a positive } \\
\text { influence on performance }\end{array}$ & 0.001 & Proven \\
\hline 4 & $\begin{array}{c}\text { Organizational trust has a positive } \\
\text { influence on performance }\end{array}$ & 0.001 & Proven \\
\hline 5 & $\begin{array}{c}\text { There is a positive influence between } \\
\text { innovative behavior on performance }\end{array}$ & 0.002 & Proven \\
\hline 6 & $\begin{array}{c}\text { Authentic leadership towards } \\
\text { performance through innovative } \\
\text { behavior }\end{array}$ & 0.039 & Proven \\
\hline 7 & $\begin{array}{c}\text { Organizational trust in performance } \\
\text { through innovative behavior }\end{array}$ & 0.003 & \\
\hline
\end{tabular}

Table 2: Summary of Hypothesis Test Results

Source: Primary data processed 2019

$\mathrm{P}$-value $<0.05$ at the $5 \%$ significance level ( $\alpha 5 \%$ ) then Ha is accepted and Ho is rejected, otherwise if the t-value $<1.96$ and or p-value> 0.05 at the $5 \%$ significance level $(\alpha 5 \%)$ then Ha is rejected and H0 is accepted. The following hypotheses are proposed in this study:

- Ho: There is no positive influence of authentic leadership on innovative behavior.

- Ha: There is a positive and significant influence of authentic leadership on innovative behavior.

- Ho: There is no positive influence of authentic leadership on performance.

- Ha: There is a positive and significant influence of authentic leadership on performance.

- Ho: There is no positive influence of organizational trust on innovative behavior.

- Ha: There is a positive and significant influence of organizational confidence on performance.

- Ho: There is no positive influence of organizational confidence on performance.

- Ha: There is a positive and significant influence of organizational confidence on performance.

- Ho: There is no positive influence of innovative behavior on performance.

- Ha: There is a positive and significant influence of innovative behavior on performance.

- Ho: There is no positive influence of authentic leadership on performance through innovative behavior.

- Ha: There is a positive and significant influence of authentic leadership on performance through innovative behavior.

- Ho: There is no positive influence of organizational trust on performance through innovative behavior.

- Ha: There is a positive influence of an organization's trust on performance through innovative behavior.

\section{Conclusion}

Based on the results of the analysis and discussion of authentic leadership and organizational trust in improving company performance with innovative behavior as an intervening variable at BCA KCU Yogyakarta, then some conclusions can be given as follows:

- There is a significant positive influence between authentic leadership on innovative behavior as evidenced by the significance value of the t-statistic value in this relationship is 3.458>1.96, and the p-value of $0.001 \varangle 0.05$.

- There is a significant positive influence between authentic leadership on performance as evidenced by the significance value of the t-statistic value in this construct relationship is 3.277> 1.96, and the p-value of 0.001 $\varangle 0.05$.

- There is a significant positive influence between organizational trust towards innovative behavior as evidenced by the significance value of the t-statistic value in this construct relationship is $4.647>1.96$, and the p-value 0.000 $\varangle 0.05$.

- There is a significant positive influence between organizational confidence in performance as evidenced by the significance value of the t-statistic value in this relationship is $3.382>1.96$, and the p-value of $0.001<0.05$. 
- There is a significant positive influence between innovative behavior on performance as evidenced by the significance value of the t-statistic value in this construct relationship is 3.181>1.96, and the p-value of 0.001 $\varangle 0.05$.

- There is an indirect effect of authentic leadership on performance through innovative behavior as evidenced by the significance value of authentic leadership on innovative behavior with a t-statistic value $3.458>1.96$. Then, the significance value of authentic leadership on performance with a t-statistic value of 3.277>1.96. Meanwhile, the significance value of innovative behavior towards performance with a t-statistic value 3.181>1.96. Then based on the significance value of each path, it is stated that there is an indirect influence of authentic leadership on performance through innovative behavior.

- There is an indirect effect of organizational trust on performance through innovative behavior as evidenced by the significance value of organizational trust in innovative behavior with a t-statistic value $4.647>1.96$. Then, the significance value of the organization's trust in performance with a t-statistic value of 3.382>1.96. Meanwhile, the significance value of innovative behavior towards performance with a t-statistic value 3.181>1.96. Then based on the significance value of each path, it is stated that there is an indirect effect of organizational trust on performance through innovative behavior.

\section{Suggestions}

Researchers with several considerations, suggest for researchers who will conduct research on the same topic, to:

- Conduct research in various sectors. Thus, the results of the study can later be represented and can also be generalized to all employees in every sector.

- Researchers suggest to further explore the construct of employee empowerment and its relationship to other variables, because this construct is still very rarely a variable in a study.

- Researchers suggest that the organization needs to conduct regular evaluations in improving company performance by using authentic leadership in order to improve employee innovative behavior so as to improve performance within the company.

\section{References}

i. Abdullahi Hasan Gorondutse. (2018). Does organizational culture matter in the relationship betwwen trust and SMEs Performance.

ii. Abraham carmeli. (2006). Self leadership skills and innovative behavior at work. Hal 75-85.

iii. Abraham Carmeli, \& Gretchen M. Spreitzea. (2009). Trust, Connectivity, and Thriving: Implications for Innovative behaviours at work.Vol 43. No.3.

iv. Avolio, B. J., Gardner, W. L., Walumbwa, F. O., Luthans, F., \& May, D. R. (2004). Unlocking the mask: A look at the process by which authentic leaders impact follower attitudes and behaviors. The Leadership Quarterly, 15 (6), 801-823. doi : 10.1016/ j.leaqua.2004.09.03.

v. Avolio, B.J. \& Luthan, F. (2006). High Impact Leaders: Moments Matter in Authentic Leadership Development. New York, MacGraw-Hill.

vi. Avolio, B.J. \& Mhatre, K.H. (2012). Adances in Theory and Research on Authentic Leadership. In K.S. Cameron \& G.Spreitzer (Eds). The Oxford Handbook of Positive Organizational Scholarship. Hal 773- 783. Oxford: Oxford University Press.

vii. Barney, Jay. (1994). Looking Inside for Competitive Advantage. Briarcliff Manor, New York: Academy of Management.

viii. Barners. J.G. (2003). Secrets Of Customer Relationship Management. Yogyakarta: ANDI.

ix. Baron, R. M., \& Kenny, D. A. (1986). The moderator-mediator variable distinction in social psychological research: Conceptual, strategic, and statistical considerations. Journal of personality and social psychology, 51(6), 1173.

x. Bastian, Indra. (2001). Akuntansi Sektor Publik di Indonesia. Edisi Pertama.Yogyakarta: BPFE.

xi. Bateman, S\& Snell. (2008). Manjemen Kepemimpinan dan Kolaborasi Dalam Dunia Pendidikan Yang Kompetitif. Jakarta: Salemba Empat.

xii. Bca.co.id/ / media/ Files/ Report/ Tahunan/ 20190313-ar-bca-ina.ashx. Di akses pada tanggal 25 april 2019. Pukul 20.45 WIB

xiii. Bernandi \& Rusel. (1993). Human Resource Management. New Jersey: International Edition Upper Saddle River, Prantice Hall.

xiv. BPSYogyakarta. (2017). DIY Dalam Angka. Yogyakarta: BPS

xv. Brockner, Joel, Phyllis A. Siegel, Joseph P. Daly, Tom Tyler, dan Christopher Martin. 1997. "When trust matters: the moderating efeect of outcome favorability." Administrative Science Quarterly 42: 558-83.

xvi. Bruhn, M. (2003), Pemasran relasional : Management of costumer relasionship,1st edn. New Jersey: Prentice Hall.

xvii. Bungin, Burhan (2001) Metodologi Penelitian Kualitatif Dan Kuantitatif. Y Yogyakarta:Gajah Mada Press.

xviii. Bursa Muceldili, Haldun Turan, Oya erdil. (2013). The influence of authentic leadership on creativity and innovativeness. Hal 673-681.

xix. Charles, H. \& David, F. (2013). Improving sales people's trust in the organization, moral judgment and performance through transformational leadership. Vol. 28. No. 7. Hal. 535-546.

xx. Castells, Manuel. (2004). The Network Society, A Cross-cultural Perspective. Massachusets: Edward Elgar Publishing Inc. 
xxi. Chan \& Chan. (2005). Impact of Perceived Leadership Styles on Work Outcomes. Case of Building Professionals. Constr. Eng. Manage. Hal. 413-422.

xxii. Crawford, M.L. (2001). Teaching Contextually: Research, Rationle, and Techniques for Improving Student Motivation and Achievment in Mathematics and Science. Waco, Texas, USA: Cord CCI Publishing.

xxiii. Coleman \& Bush. (2006). Leadership And rategic Management in Education.London: A SAGE Publications Company.

xxiv. De Jong, J.P.J \& R, Kemp. (2003). Determinants of Co-workers Innovative Behaviours. An Investigation Into Knowledge Intensive Service. International Journal of Innovation Management. Vol. 7. No. 2. Hal.189-212.

xxv. De Jong, J., \& Den Hartog, D., (2010). Measuring Innovative Work Behavior. Journal of Creativity and Innovation Management. Hal 23-36

xxvi. Delgado-Ballester, E. (2003). "Applicability of Brand Trust Scale across Product Category", European Journal of Marketing, 38 (5). Hal. 573-592.

xxvii. Deutsch \& Coleman (2006). the handbook of conflict resolution: theory and practice.

xxviii. Dubrin A.J. (2005). Leadership (Terjemahan). Edisi kedua.Jakarta: Prenada Media.

xxix. Eagly, A.H. (2005). Achieving Relational Authenticity Leadership: Does Gender Matter ? The Leadership Quarterly. Vol. 16. Hal. 459-474.

xxx. Falcone and, Castelfranchi. 2004. Trust dynamics: How trust is influenced by direct experiences and by trust it self. In Proceedings of the $3^{\text {rd }}$ InternationalConference on Autonomous Agents and Multi-Agent System (AAMAS04),. New York, ACM.

xxxi. Gani, I., \& Amalia, S. (2015). Alat Analisis data. Yogyakarta: Andi Offset.

xxxii. Ghozali, Imam. 2013. Aplikasi Analisis Multivariate dengan Program IBM SPSS 21 Update PLS Regresi. Semarang: Badan Penerbit Universitas Diponegoro.

xxxiii. G Gendra, Poerwanto. (2012). Manajemen Kualitas. Jakarta: PT Gramedia Pustaka Utama.

xxxiv. Gaynor, G.H. (2002). Innovation by Design. New York, American Management Association.

xxxv. Gomes, Faustino Cardoso. (2000) Manajemen Sumber Daya Manusia, Cetakan Keempat. Yogyakarta. Penerbit Andi.

xxxvi. Gurviez, Patricia dan Korchia, Michael. (2003). Proposal for a Multidimensional Brand Trust Scale, 32nd EmacConference-Glasgow. Marketing: Responsible and Relevant.

xxxvii. Hair et al. (2010). Multivariate Data Analysis, Seventh Edition. Pearson Prentice Hall

xxxviii. Hank. (2002). Coorporat Govermance and Intellectual Capital: Consepyualisations. Corporat Govermance. Vol. 9. No. 4. Hal. 259-275.

xxxix. Hoogendoorn., Jaffry., Treur., (2009). Adaptive Agent Model Estimating Human Trust In Information Sources. Los Amilatos, Computer Society Press.

xl. Hyo kyoung kim. (2014). The effect of authentic leadership on employees attitudes behaviors and performance in a korean context.Vol. 18, No. 3, 259-277.

xli. Hyo Min Seo, Min Cheol Kim, Kyong Gro Chang, \& Taehee Kim. (2015). Influence of interpersonal trust on innovative behaviours of service workers: Mediating effect of knowledge sharing. Vol. 20. No.2.

xlii. Jacob Guinot. (2014). Organizational trust and performance: Is organizational learning capability a mising link. Vol. 19. Hal. 559-582.

xliii. Johnson \& Johnson. (1997). Emotional Intellegence, Ney Jersey, Prentice Hall Inc.

xliv. Johnson, D. W. \& Johnson, F. P. (2000). Joining together: group theory and group skill. Pearson Education Company: New York.

xlv. Kerstin Alfes Amanda Shantz Ratnesvary Alahakone.(2016). Testing additive versus interactive effects of personorganization fit and organizational trust on engagement and performance. Personnel Review, Vol. 45 Iss 6.Hal. 1323-1339.

xlvi. King. (2002). The Resurgence Of Intellectual Capital: The Emphasis Shift From Measurement to Management. Jerman.

xlvii. $\quad$ Locander, W.B., F. Hamilton \& J. Stuart. (2002). Developing a leadership- rich culture: The missing link to creating a market-focused organization. Journal of Market-Focused Management. Vol. 5, pp. 149-163.

xlviii. Lussier, R.N. \& Achua (2010). C.F. Effective Leadership (edisi 4). New Jersey, Pearson Prentice Hall

xlix. Mangkunegara. A.P. (2005). Evaluasi Kinerja Sumber Daya Manusia. Bandung: Refika Aditama

1. Mariages. (2001). Corporate Govermance in Knowledge Economy. The Relevance of The Intellectual Capital. India, Research Project. Pondicherry.

li. Marhiot T.E. (2002). Manajemen Sumber Daya Manusia. Jakarta: Grasindo.

lii. Mas'ud. (2004). Survai Diagnosis Organisasional (Konsep dan Aplikasi). Semarang: Universitas Diponegoro.

liii. Mathew Hughes.(2018). Innovtive Behaviour, trsut, and preceived workplace performance. Loughborough University.

liv. Min-Seong Kim \& Dong Woo Koo. (2017). Linking LMX, engagement, innovative behavior, and job performance in hotel employees, International Journal of Contemporary Hospitality Management. Vol.29. N0.12.

lv. Moekijat. (2003). Manajemen Sumber Daya Manusia.Jakarta: Rineka Cipta.

lvi. Morgan, Robert M., dan Shelby D. Hunt. (1994). "The Commitment-Trust Theory of Relationship Marketing", Journal of Marketing, Vol. 58, July, pp. 20-38

lvii. Mualizir, Musnadi, Yunus. (2012). Pengaruh Kepemimpinan Transaksional dan Transformasional Terhadap Kinerja Karyawan Bank Syariah Mandiri Cabang Banda. Vol. 1. Hal. 1-13. 
lviii. Muhammad Anwar ul Haq, Muhammad Usman, \& Shaista Khalid. (2018). Employee, Empowerment, trust, and innovative behaviours: Testing a Path Mode. Vol 9. No. 2.

lix. Muhammad Ansar. (2017). The Impact Visionary Leadership, Learning Organization and Innovative Behavior to Performance of Customs and Excise Functional. Vol. 1 No. 2. Hal 52-60.

lx. Nadin Dorner. (2012). Innovative Work Behavior: The Role of Employee Expectations and Effect on Job Performance. Desertation No.4007.

lxi. Neuza ribeiro. (2017). Authentic leadership and performance, the mediating role of employees affective commitment. Vol.14. Hal. 213-225.

lxii. Nimran. (2004). Perilaku Organisasi. Cetakan ketiga. Surabaya: CV. Citra Media.

lxiii. Nista Malik. (2010). Authentic Leadership - an Antecedent For Contextual Performance of Indian Nurses.

lxiv. Omarov, A. (2009). Örgütsel Güven ve İş Doyumu: Özel Bir Sektörde Uygulama. (Yayımlanmamış Yüksek Lisans Tezi). Dokuz Eylül Üniversitesi Sosyal Bilimler Enstitüsü, İzmir.

lxv. Paille, P., Bourdeau, L., and Galois, I. 2010. Support, Trust, Satisfaction, Intent to Leave, and Citizenship at Organizational Level. International Journal of Organitazional Analysis, 18 (1):41-58.

lxvi. Pasolong, Harbani. (2010). Teori Administrasi Publik, Alfabeta, Bandung.

lxvii. Pavlou PA. (2002). Consumer Acceptance of Electronic Commerce: Integrating Trust and Risk with The Technology Acceptance Model. International Journal of Electronic Commerce.

lxviii. Peiyan Huang. (2017). A Framework for Research and Practice:Relationship among Authentic Leadership,Employee Well-Being, Organizational Innovative Climate and Innovative Behavior. Hal 126-134.

lxix. $\quad$ Price, J.L. (1997). Handbook of Organizational Measurement. International Journal Of Manpower. Hal. 335- 358.

lxx. Pucetaite. Et.el. The Relationship between Ethical Organisational culture and Organisational innovativeness: Comparison of Findings from Finland and Lithuania. Bus Ethics. (2016) 139:685-700. Springer.

lxxi. Purba, Sutrisno. (2009). Pengaruh budaya organisasi, Modal Intelektual dan Perilaku Innovatif terhadap kinerja pemimpin. UNM. Vol.13. No. 2.

lxxii. Rachel clapp smith. (2009). Authentic leadership and positive psychologucal capital the mediating role of trust at the group level of analysis. Hal. 227-240.

lxxiii. Rank, J., Nelson, N.E., \& Allen, T.D. (2009). Leadership Predictor of Innovation and tasks Performance: Sub Ordinates Self Esteem and Self Presentation as Moderator. Journal Of Occupational and Organizational Phsycology. Hal. 456-489.

lxxiv. Rivai, Veithzal. (2009). Manajemen Sumber Daya Manusia Untuk Perusahaan Dari Teori ke Praktik. Jakarta: Raja Grafindo Persada.

lxxv. Robin Deman, Ann Jorissen, Eddy Laveren. (2018).Family control and innovativeness in private firms: the mediating role of board task performance.Vol 56. No. 2. Hal. 259-310.

lxxvi. Robbins, Stephen P. (2001). Perilaku Organisasi: Konsep, Kontroversi, Aplikasi, Jilid1, Edisi 8, Prenhallindo, Jakarta.

lxxvii. Robbins S.P. (2002). Perilaku Organisasi. Edisi Kelima. Jakarta: Erlangga.

lxxviii. Robbins, Stephen. P. (2006). Perilaku Organisasi (alih bahasa Drs. Benjamin Molan), Edisi Bahasa Indonesia, Klaten: PT Intan Sejati.

lxxix. Robbins S.P. (2011). Perilaku Organisasi. Jakarta: Salemba Empat.

lxxx. Sadili Samsudin. (2005). Manajemen Sumber Daya Manusia. Pustaka Setia. Bandung.

lxxxi. S,ahin Danis,man, S,uleBetul Tosuntas, and Engin Karadag, (2015). The Effect of Leadership on Organizational Performance. Hal. 143-168.

lxxxii. Seok Hwan Lee. (2008). The Effect of Employee Trust and Commitment on Innovative Behavior in the Public Sector: An Empirical Study. Vol 18. Hal. 27-46.

lxxxiii. Shamir, B. \& Eilam, G. (2005). A Life Story Approach to Authentic Leadership Development.Leadership Quarterly, Vol.16. Hal 395-417.

lxxxiv. Shahid Nawaz Khan. (2010). Impact of Authentic Leaders on Organization Performance. Vol. 5. No.12. Hal. 167171.

lxxxv. Siagan S.P. (2002). Teori dan Praktik Kepemimpinan (Cetakan Kelima). Jakarta: Rineka Cipta.

lxxxvi. Solomon, L.J \& Rothblum, E.D. 2001. Academic Procrastination: Frequency and Cognitive-Behavioral Correlates, Journal of Counseling Psychology. No.31.504-510.

lxxxvii. Srimindarti, Ceacilia. (2004). Balanced Scorecard Sebagai Alternatif untuk Mengukur Kinerja. Fokus Ekonomi. Vol. 3, No. 1.

lxxxviii. Stefano Battiston, FrankE. Walter, Frank Schweitzer. (2006). Impact of Trust on the Performance of a Recommendation System in a Social Network. Vol. 16. Hal. 57-74.

lxxxix. Sugiyono. (2009). Metode Penelitian Pendidikan, Pendekatan Kuantitatif, Kualitatif dan R\&D. Bandung: Afabeta.

xc. Sutikno, Sobry M. (2014). Pemimpin dan Gaya Kepemimpian. Edisi pertama. Lombok: Holistica.

xci. Tondok \& Andarika. R. (2004). Hubungan Antara Gaya Kepemimpinan Transformasional dan Transaksional Dengan Kepuasan Kerja Karyawan. Palembang. Fakultas Psikologi Universitas Bima Darma

xcii. UMKM Jogja. (2019, Maret 14). Berita UMKM. Retrieved from umkmjogja.id: https:// umkmjogja.id/ peran-umkmdalam-pertumbuhan-ekonomi-rakyat/

xciii. Urip Sedyowidodo \& Tri Susanto. (2013). Analisis Pengaruh Pemikiran Kreatif dan Perilaku Innovatif Terhadap Kinerja dengan Metode SEM. Hal 381-395. 
xciv. Wank destriandi. (2016). Kepemimpinan otentik dan kepercayaan sebagai prediktor kinerja anggota kelompok binaan dinas kelautan dan perikanan di kabupaten kaur. Hal 72-85.

xcv. Waleed Omri. (2015).Innovative Behavior and Venture Performance of SMEs: the Moderating Effect of Environmental Dynamism. Vol. 18. No. 2.

xcvi. Walumbwa, F., Avolio, B., Gardener, W., Werbsung, T., \& Peterson, S. (2008). Kepemimpinan Otentik: Development and Validation of a Theory Based Measure. Vol. 34. No 1. Hal 89-126.

xcvii. West, M. A and Farr, J. L. 1990. Innovation and creativity at work: Psychological and Organizationan Strategies. Chichester: Wiley.

xcviii. West, M.A. \& Altink, W.M.M. (1996). Innovation at Work: Individual, Group, Organizational, And Socio Historical Prespectives, European Journal of Work and Organizational Phsycology. Vol 5. No.1. Hal 3- 11.

xcix. Wibowo. (2009). Manajemen Kinerja. PT. Raja Grafindo Persada: Jakarta.

c. Zainuddin \& Abdul Mustaqim. (2015). Studi Kepemimpinan Islam: Telaah Normatif dan Historis. Semarang: Putra Mediatama Press.

ci. Zalabak-Shockley. (2010). Building the High-Trust Organization: Strategies for Supporting Five Key Dimensions of Trust. USA: JosseyBass. 